\title{
Fuzzy Logic Based Power Factor Correction in Single Phase AC-DC System
}

\author{
Mehmet Akif ŞENOL* \\ Beykent University, Faculty of Engineering and Architecture, Department of Electrical-Electronics Engineering, \\ Istanbul, Turkey \\ (ORCID: 0000-0002-3797-1965)
}

\begin{abstract}
In recent years, there has been a significant increase in the number of power electronics converters used in both industrial and home appliances devices. The utilization of electronic ballasts and switching mode power supply in power conservation introduced the trouble of power quality. The currents used by these devices are not sinusoidal and these currents are known as non- linear. Boost type power factor correction (PFC) converters are becoming popular due to their conformity in power system quality problems. Conventionally, power factor correction converters were controlled using Proportional-Integral- Differential (PID) controller to reduce harmonic disturbances and enhance the power factor (PF). Conversely, for non-linear system, their performances are not very acceptable. Because PFC circuit is not linear, in this paper fuzzy logic (FL) controller used to adjust the gain PID controller to improve the performance is presented. It is proposed that when there is fluctuation in the voltage input, the input current should be made by a FL controller. This FL controller has a great effect by keeping the phase angle between current and voltage at a very small value, bringing the PF factor closer to 1.0. This great effect has also been demonstrated in experimental studies. The proposed FL based PFC controller converter is analyzed in MATLAB/Simulink environment under variable loads and different voltages. The Performance results (total harmonic distortion, PF and efficiency) has been calculated for different input voltage and different loads. From these results it can be seen that the PF value is always improved to a value greater than 0.985 , efficiency is more than $85 \%$ and total harmonic distortion of current is around $4 \%$ to $12,5 \%$. The performance results of the FL based PFC is in acceptable ranges in terms of THD according to IEC 61000-3-2. For the THD values the cubic polynomial regression analysis was performed in MATLAB/ Basic Toolbox. (Version R2020b).
\end{abstract}

Keywords: Power factor correction (PFC), fuzzy logic (FL), total harmonic distortion (THD), AC-DC rectifier, boost converter.

\section{Tek Fazlı AC-DC Sistemde Bulanık Mantık Tabanlı Güç Faktörü Düzeltmesi}

\section{$\ddot{O} \mathbf{z}$}

Son yıllarda hem endüstriyel hem de ev ve benzeri yerlerde kullanılan alet ve cihazlarda bulunan güç elektroniği dönüştürücülerinin sayısında önemli bir artış olmuştur. Güç tasarrufunda elektronik balastların ve anahtarlamalı güç kaynağının kullanılması güç kalitesi sorununu beraberinde getirmiştir. Bu cihazların kullandığı akımlar sinüzoidal değildir ve bu akımlar doğrusal olmayan akımlar olarak bilinir. Yükseltici (boost) tipi güç faktörü düzeltme (PFC) dönüştürücüleri, güç sistemi kalite sorunlarındaki uygunlukları nedeniyle popüler hale gelmiştir. Geleneksel olarak, güç faktörü düzeltme dönüştürücüleri, harmonik bozulmaları azaltmak ve güç faktörünü (PF) geliştirmek için Oransalİntegral-Diferansiyel (PID) denetleyici kullanılarak kontrol edilmektedir. Ancak bunların, doğrusal olmayan sistem için performansları çok kabul edilebilir değildir. PFC devresi doğrusal olmadığından, bu makalede, performansı iyileştirmek için kazanç PID denetleyicisini ayarlamak için kullanılan bulanık mantık (FL) denetleyicisi öngörülmüştür. Gerilim girişinde dalgalanma olduğu zaman, giriş akımının bir FL kontrolörü tarafından yapılması önerilmektedir. Bu FL kontrolör, akım ve gerilim arasındaki faz açısını çok küçük bir değerde tutarak PF faktörünü 1.0'a yaklaştırarak büyük bir performansa sahiptir. Bu büyük performans, deneysel çalışmalarla da gösterilmiştir. Önerilen FL tabanlı PFC denetleyici dönüştürücü, MATLAB / Simulink ortamında değişken yükler ve farklı gerilimler altında analiz edilmiştir. Performans sonuçları (Toplam harmonik bozulma, PF ve verimlilik) farklı giriş gerilimleri ve farklı yükler için hesaplanmıştır. FL tabanlı PFC'nin performans THD sonuçları IEC 61000-3-2'e göre kabul edilebilir aralıklardadır. THD değerleri için MATLAB/Basic Toolbox'da (R2020b versiyonu) kübik polinomlu regresyon analizi yapılmıştır.

Anahtar kelimeler: Güç faktörü düzeltme (PFC), bulanık mantık (FL), toplam harmonik bozulma (THD), AC-DC doğrultucu, yükseltici (boost) tip dönüştürücü

\footnotetext{
*Corresponding author: akifsenol@beykent.edu.tr
}

Received:17.02.2021, Accepted: 19.04.2021 


\section{Introduction}

Now day's electric power has been used in the different linear and nonlinear loads. The nonlinear loads used in the power system are energy efficient ballasts, solid state motor system and personal computers etc. The shape of the current is non-sinusoidal due to nonlinear loads and it introduced the trouble of power quality. Modern rectifiers and associated devices are drawing the non-sinusoidal current and it is distorted with harmonics. Generally, a switched mode power supply uses the diode rectifier in the ACDC conversion systems. Due to diode rectifier, input current of the AC system draws the non-sinusoidal current i.e., short pulsating current [1]. The peak value of the current is always high in the diode rectifier to supply the same amount of power in form of short pulses. Due to this effect, electrical distribution system components such as circuit breakers, wiring, etc. are under stress. Due to this, harmonics are generated in the current, PF of the supply system is reduced due to non-sinusoidal current and total harmonic level not at standard level [2]. To reduce the stresses in the equipment of the power system and increase the real power flow from input to load side, PFC circuit could be added in the power system to enhance the shape of the input current and PF circuit should modify to unity angle between current's phasor and voltage's phasor of the input supply system [3,4].

The PFC is very important in the power electronic system and it is most powerful technique in power electronics system. PFC can be classified into two areas, one is passive PFC and second one is active PFC. The passive elements are used in passive PFC such as inductor and capacitor. This will modify the non-sinusoidal current into sinusoidal current but this method not control the output dc voltage at constant level. The semiconductor device incorporates with passive elements to modify the input current's shape as well as regulate the output de voltage of the AC-DC system.

Normally, active PFC circuits utilize the function of the boot, buck-boost DC-DC converter after rectifier circuit of the AC-DC system and it will improve the power factor of the system [1-3]. Most of the PF circuits are uses the Buck or boost converter topology because it has high PF capability.

Conversely, losses are arise in the diode bridge rectifier in conservative PFC circuits. Normally, current of the AC-DC system are passes through the power semiconductor elements at each switching cycles. The converter efficiency reduces due to forward voltage drop and losses in the diode bridge rectifier. In order to overcome this problem, more research efforts are done by the researcher for developing the bridgeless based PFC techniques. The current will flow minimum number power semiconductor elements in the bridgeless PFC circuit which leads to reduce the losses and increases the efficiency of the system and also enhance the PF of the system [5-8].

Normally, PFC and output regulation of the single phase AC-DC system is developed using proportional integral controller but it has some disadvantages such as to obtain gain parameter of the proportional integral controller, it need exact model of the system and it is more complex for the considered system. Normally, gain parameter of the system is obtained by means of trial and error method but this method takes more time to tune the gain parameter of the PI controller. In general, gain parameter of the PI controller id fixed for all operating conditions of the system but it will degrade the system performance. In order to overcome these problems, in this paper FL controlled PFC and output voltage controller is designed for single phase AC-DC system $[9,10]$. The organization of the paper as follows, DC-DC boost converter for single phase AC-DC system is explained in section 2. Voltage regulation by fuzzy tuned PI controller is described in the section 3. MATLAB simulation and results are discussed in the section 4 . In section 5, concluding remarks are provided.

\section{Material and Method}

\subsection{Boost Converter for Single Phase AC-DC System}

The block diagram for single phase AC-DC boost converter system is shown in Fig. 1. The boost converter circuit is connected at the output end of the bridge rectifier and rectifier is connected to input ac supply system. The boost converter consists of the diode, inductor, and power semiconductor elements. The output is taken from the capacitor $\mathrm{CO}$ and this voltage always constant. The output of the capacitor is connected with resistive load. 


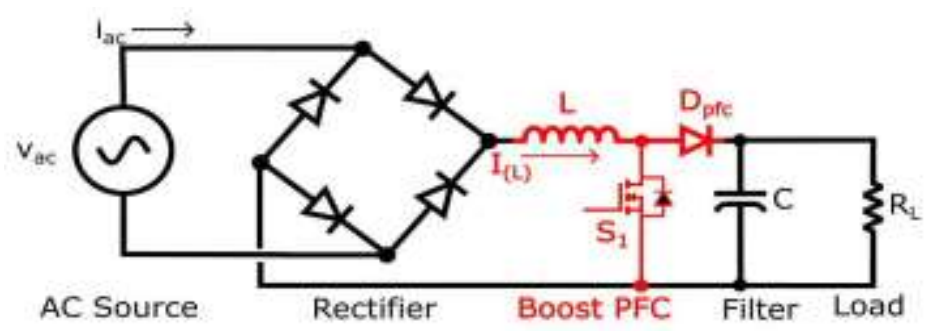

Figure 1. AC-DC boost converter system

It has two modes of operation according to the state of the switch. In the first mode of operation the switch is in on state $(u=1)$, the inductor current accumulates and inductor stores the energy in form magnetic effect and the load is supplied by the capacitor. For this conditions inductor voltage is given by the following equation,

$$
v_{L}=V_{s}=L \frac{d i_{L}}{d t}
$$

and capacitor current is given by the following equation

$$
i_{c}=C \frac{d v_{c}}{d t}
$$

The second mode of operation is obtained by turning the switch to off state $(\mathrm{u}=0)$. Inductor current cannot change suddenly and the diode becomes forward biased providing way for the inductor current. The energy stored in the inductor together with the input source transferred to the output. In this case voltage across the inductor becomes

$$
v_{L}=V_{s}-v_{c}=L \frac{d i_{L}}{d t}
$$

the inductor current is given by following equation,

$$
i_{L}=i_{c}+i_{R}=C \frac{d v_{c}}{d t}+\frac{v_{c}}{R}
$$

by considering capacitor voltage and the current through the inductor as state variable and combining equations (1), (3) and (2), (4) with $\mathrm{u}$ which is the control input taking the discrete values 0 and 1 representing the switch position then we have

$$
\begin{aligned}
& \frac{d i_{L}}{d t}=-(1-u) \frac{v_{C}}{L}+\frac{V_{S}}{L} \\
& \frac{d v_{C}}{d t}=(1-u) \frac{i_{L}}{C}+\frac{v_{C}}{R C}
\end{aligned}
$$

\subsection{Fuzzy logic based regulation voltage in AC-DC system}

The output voltage of the AC-DC system is controlled by means of the closed loop manner. The fuzzy inference systems are considered as a nonlinear control system of the FL system. The fuzzy inference system process the input values in between 0 to 1 i.e., fuzzy value. The major steps involved in the design of the FL system is fuzzification, rule base and defuzzification. General structure of the FL inference system shown in Fig. 2. 


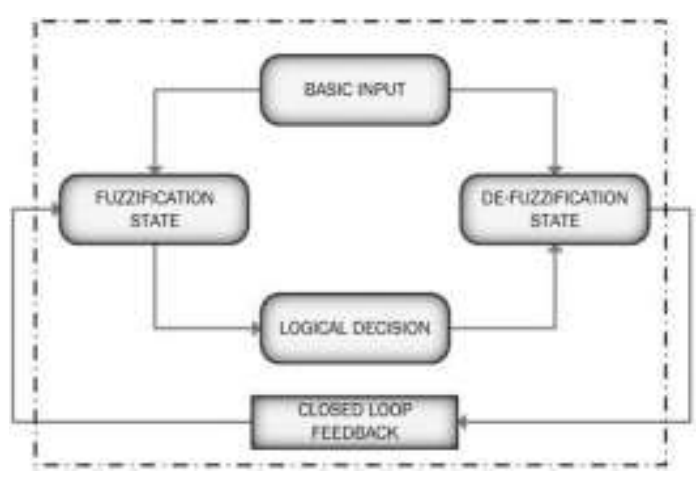

Figure 2. Fuzzy Logic control

Normally, FL system receives the two inputs such as voltage error and rate of change of voltage error. The membership functions are assigned for the input variable in fuzzification stage [11-15]. In fuzzification stage, crisp value of the input is converted into fuzzy value. Input variable are distributed with seven membership function with fourty nine rules. These fuzzy rules are used to control the system thus by regulate the output voltage of the system. Final step in the fuzzy inference system is defuzzification. In defuzzification, fuzzy value converted into crisp value.

\subsection{Fuzzy tuned PI Controller}

The arrangement of fuzzy tuned PI controller is given in figure 3 and FL is used for modification of PI controller gain at entire working conditions. In this study it is used the mamdani fuzzy inference system [16]. The arrangement of FL controller is shown in Fig. 4. It has two inputs i.e., voltage error and the rate of change of voltage error and two outputs $\left(\mathrm{K}_{\mathrm{P}}\right.$ and $\left.\mathrm{K}_{\mathrm{I}}\right)$. Each input has distributed with five bell shaped membership function.

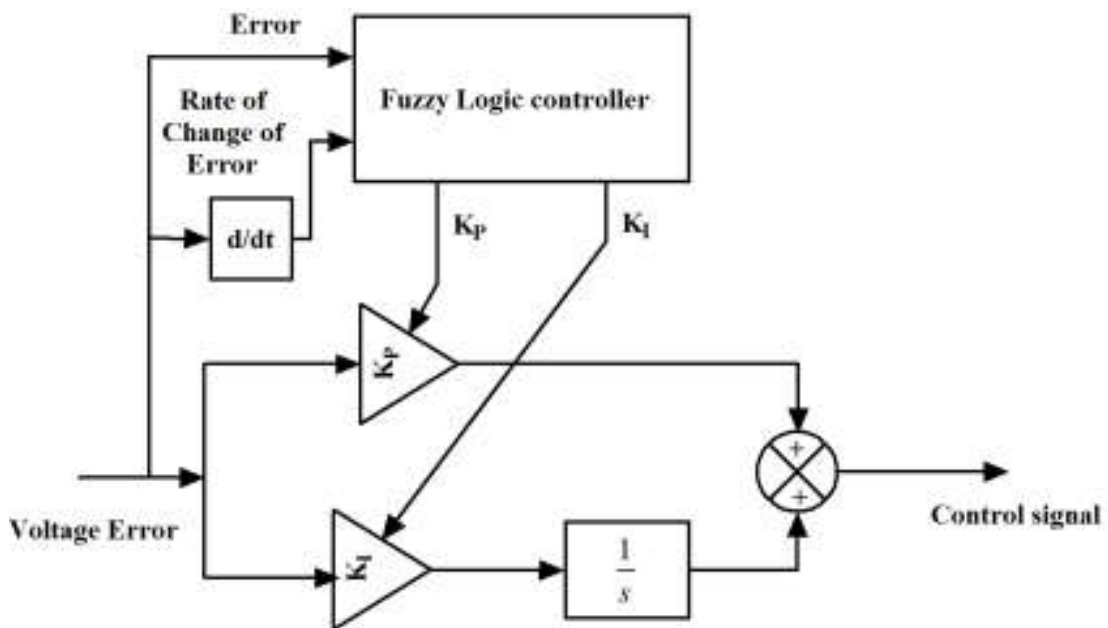

Figure 3. Fuzzy PI Controller

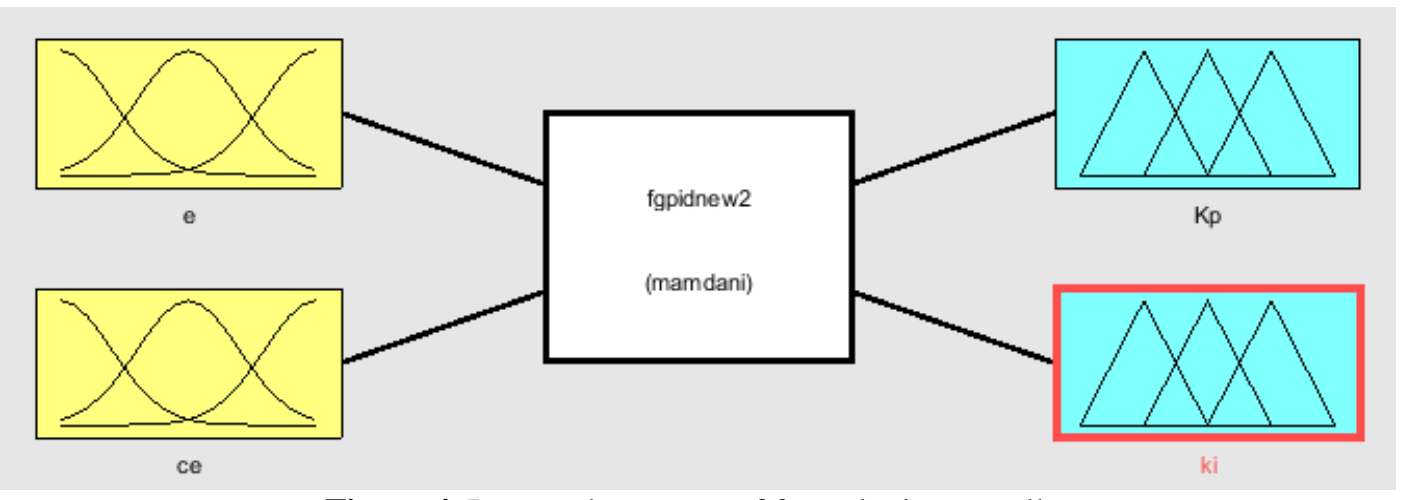

Figure 4. Proposed structure of fuzzy logic controller 
Allocation of input membership function is shown in Figure 5(a) \& (b). The general bell shaped membership function is given in the equation (7) as,

$f(x ; a, b, c)=\frac{1}{1+\left|\frac{x-c}{a}\right|^{2 b}}$

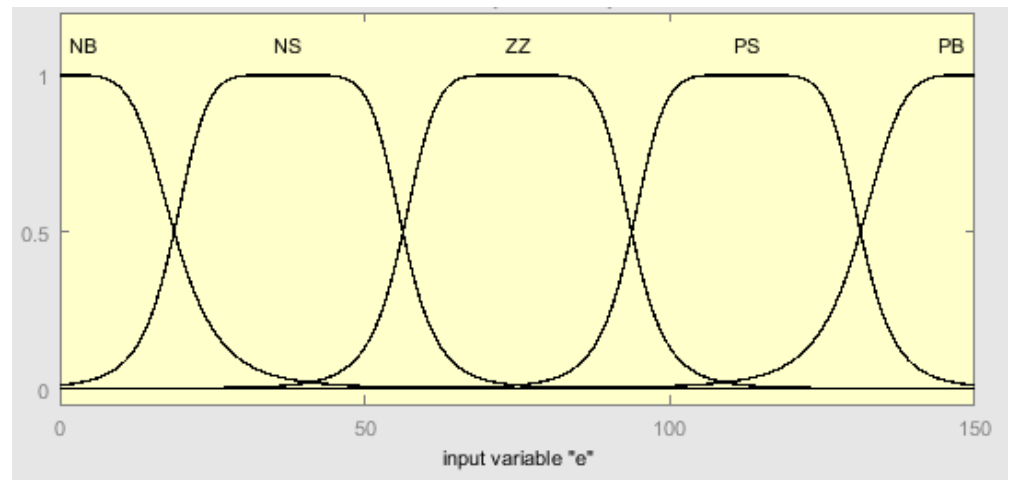

(a)

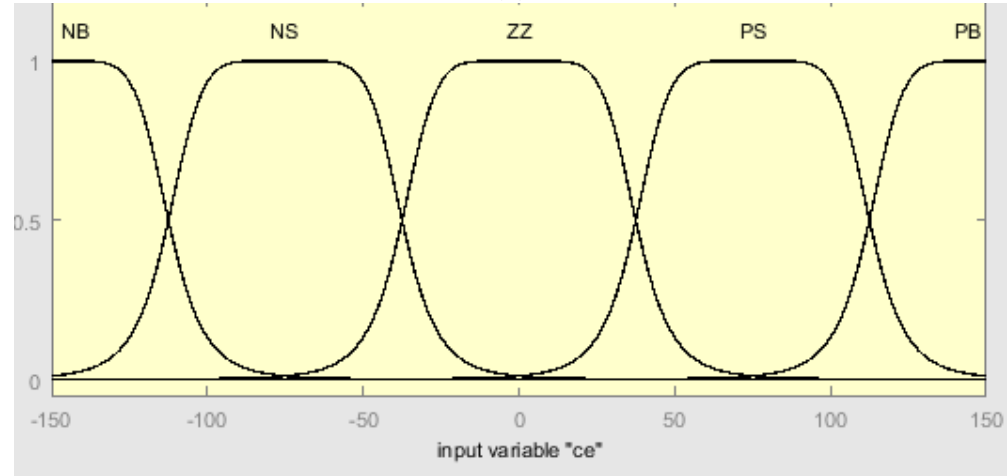

(b)

Figure 5. a) Five functions for voltage error (b) Five functions for rate of voltage error's change

Generally, three parameters determine a bell curve function. Parameter a represents half the width of the bell curve. Parameter b controls the slopes at the intersection points of the curves. Parameter $\mathrm{c}$ decides the centre of the resultant membership function. The error of the input voltage vary from 0 to 150 , rate of change of voltage error vary from -150 to 150 . Also five membership functions denoted by Positive-Small (PS), Positive-Big (PB), Negative-Small (NS), Zero (Z), and Negative-Big (NB).

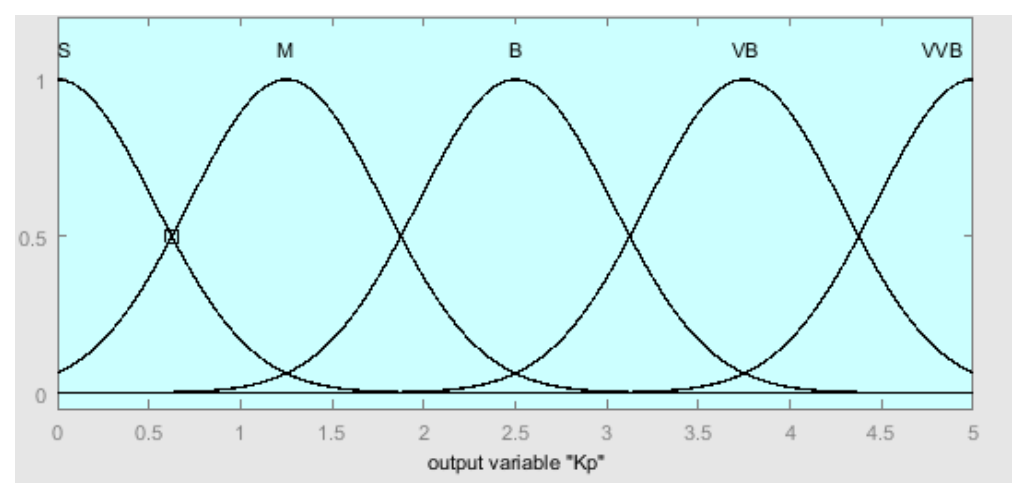

Figure 5. (c) Gaussian norms functions for rate of change of voltage error 


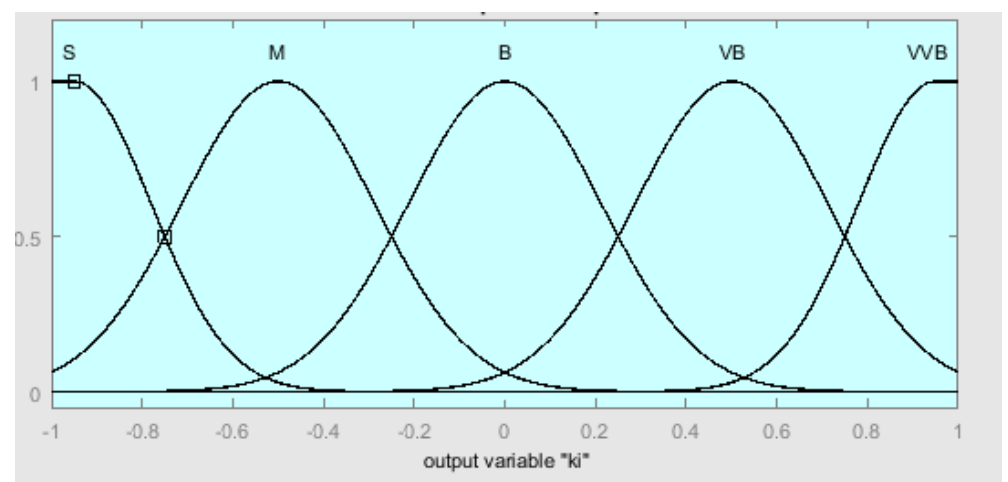

Figure 5. (d) Gaussian norms functions for rate of change of voltage error

Likewise, every output is spread with five Gaussian norms functions. These functions are shown in Figure 5(c) \& (d). The comprehensive Gaussian function is given by the following equation (8) as,

$f(x ; \sigma, c)=e^{\frac{-(x-c)^{2}}{2 \sigma^{2}}}$

In equation (8), $\mathrm{c}$ is the center of the function and $\sigma$ is width of the function [16]. These five functions are indicating by Very-Very Big (VVB), Very Big (VB), Big (B), Medium (M), and Small (S). The proportional gain change between 0 and 5 and integral gain change between -1 and 1 . In total, 25 rules occur for the FL gain tuner, and several rules are given in equation (9).

rule 1: if e is $N B$ and $\Delta e$ is $N B$ then (Kp is $V V B)(K i$ is $V V B)$ !

rule 25: if e is $P B$ and $\triangle e$ is $P B$ then (Kp is $S$ )(Ki is $S$ )

Table 1. Fuzzy rule base for fuzzy tuned PI controller

\begin{tabular}{|c|c|c|c|c|c|c|c|c|c|c|c|c|c|}
\hline \multirow{7}{*}{ 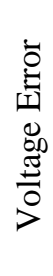 } & \multicolumn{6}{|c|}{ Rate of voltage error's change } & \multirow{3}{*}{$\stackrel{0}{0}$} & \multicolumn{6}{|c|}{ Rate of voltage error's change } \\
\hline & $\mathrm{K}_{\mathrm{P}}$ & NB & NS & $\mathrm{Z}$ & PS & PB & & $\mathrm{K}_{\mathrm{I}}$ & NB & $\mathrm{NS}$ & $\mathrm{Z}$ & PS & PB \\
\hline & NB & VVB & VB & VVB & VB & B & & NB & VB & VVB & B & B & B \\
\hline & NS & VB & VB & VVB & VB & B & $\underset{\infty}{\infty}$ & NS & VVB & VB & VVB & B & M \\
\hline & $\mathrm{Z}$ & VVB & VVB & PB & PS & PS & 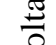 & $\mathrm{Z}$ & PB & M & $\mathrm{S}$ & $\mathrm{S}$ & $\mathrm{S}$ \\
\hline & PS & B & $\mathrm{M}$ & $\mathrm{M}$ & M & M & $>$ & PS & M & B & M & $\mathrm{S}$ & $\mathrm{S}$ \\
\hline & PB & M & $\mathrm{M}$ & $\mathrm{S}$ & M & $\mathrm{S}$ & & PB & $\mathrm{M}$ & $\mathrm{S}$ & $\mathrm{S}$ & PS & PS \\
\hline
\end{tabular}

In Table I, the overall fuzzy rule is given for the fuzzy tuner. The Fuzzy system employs the centroid defuzzification technique and it is the most widely used technique and it gives accurate results. This defuzzification gives the center of area beneath the curve. It is given by the equation (10) as,

$\operatorname{gain}_{k p, k i, k d \text { and } k c}=\frac{\int \mu A(x) x d x}{\int \mu A(x) d x}$

The output from the fuzzy tuner is then multiplied with PI controller. The output gives the control signal to the system. In Fig. 6 the simulink model of the system is given.

\section{Results and Discussions}

In order to test the effectiveness of the proposed fuzzy based PFC for single phase AC-DC system, MATLAB simulation have been carried out. The overall simulation diagram of the proposed system is shown in Fig. 7. The system consists of single phase supply, fully wave diode rectifier, DC-DC boost converter, electrical load, PFC controller with FL control and measurement systems. 


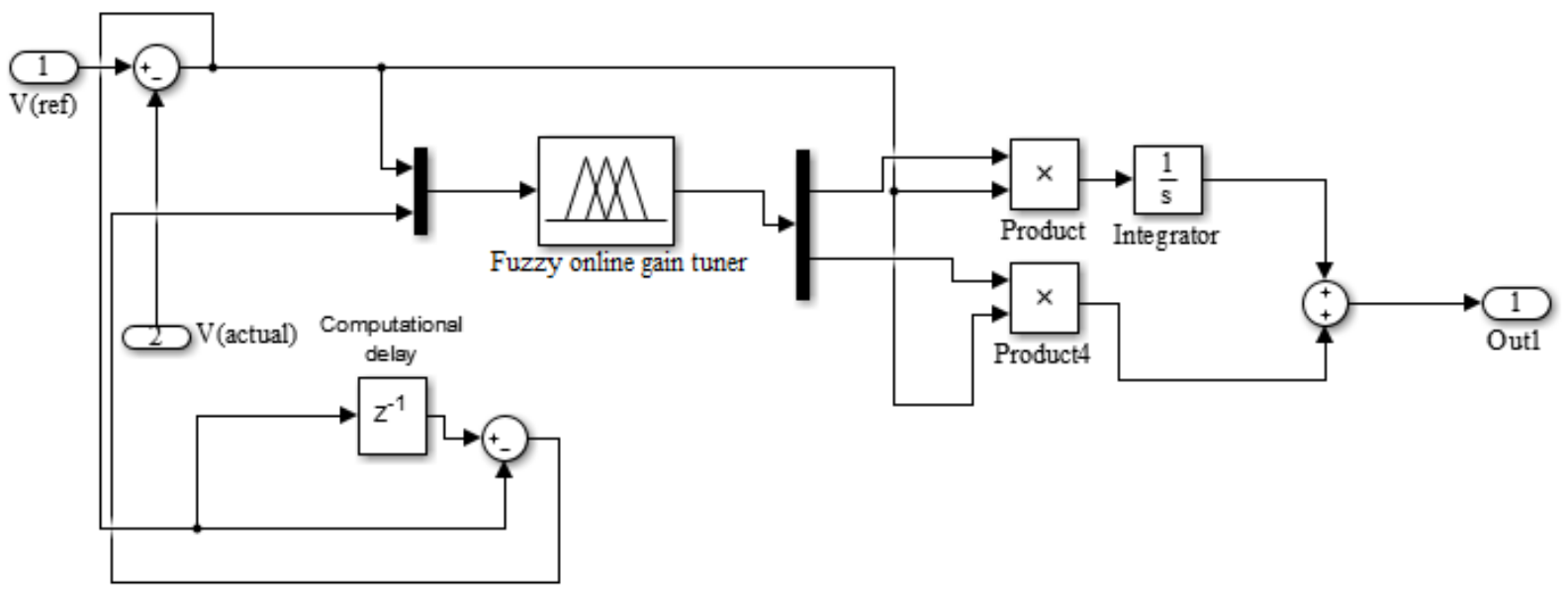

Figure 6. Simulink model of fuzzy PI controller

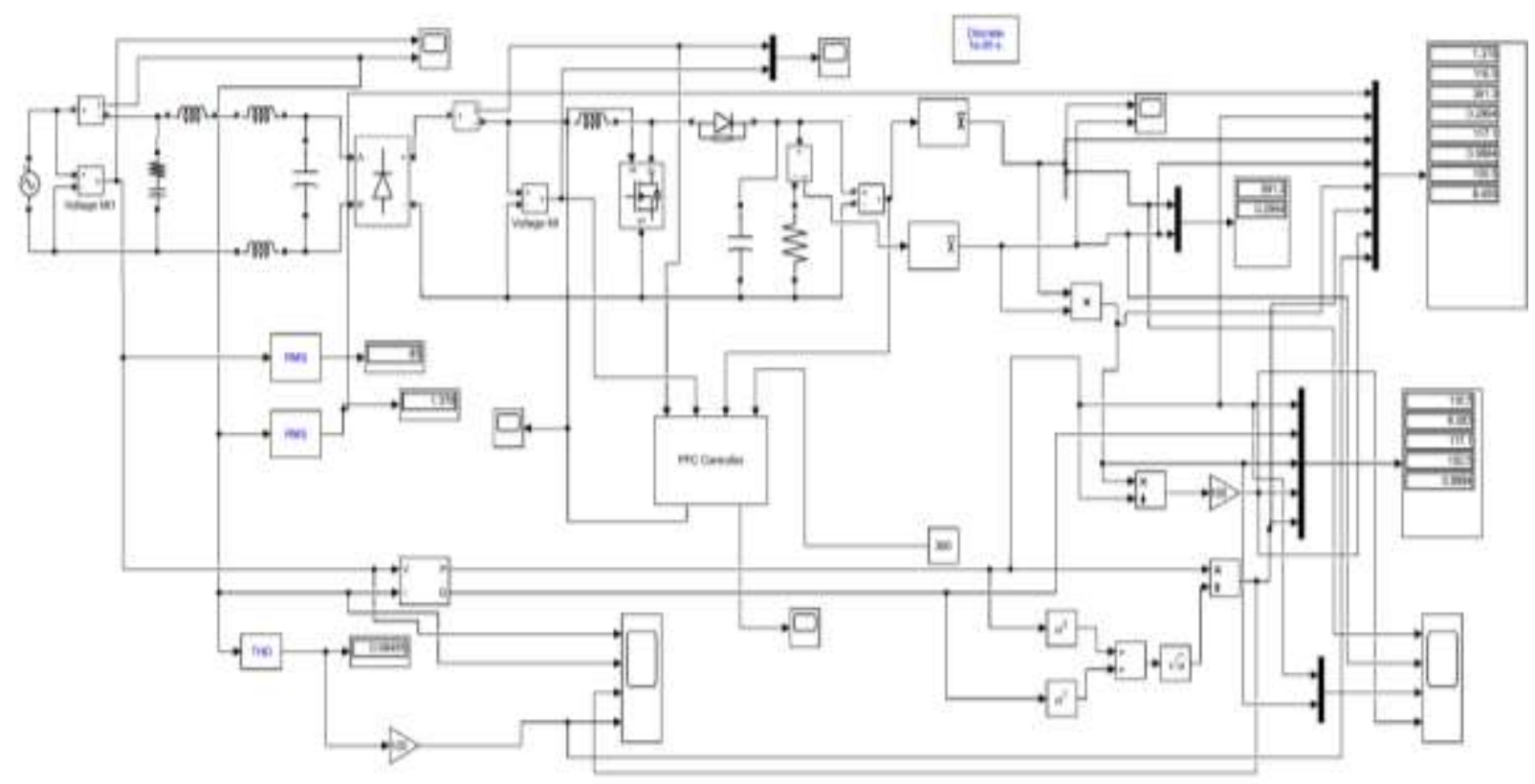

Figure 7. Overall Simulation model of the Fuzzy based PFC for single phase AC-DC systems

The singe phase system has been tested for different input voltage level such as $80 \mathrm{~V}, 95 \mathrm{~V}, 110$ $\mathrm{V}, 115 \mathrm{~V}, 125 \mathrm{~V}, 140 \mathrm{~V}, 155 \mathrm{~V}, 170 \mathrm{~V}, 185 \mathrm{~V}, 200 \mathrm{~V}$ and $220 \mathrm{~V}$ with different loading conditions such as $0.5 \mathrm{k} \Omega, 0.6 \mathrm{k} \Omega, 0.7 \mathrm{k} \Omega, 0.8 \mathrm{k} \Omega, 0.9 \mathrm{k} \Omega$ and $1.0 \mathrm{k} \Omega$. The input current, input voltage, input power, output voltage, output current, output power, efficiency, and total harmonic distortion for current is shown in Table 2 for $1.0 \mathrm{k} \Omega$ loading conditions.

From the Table 2, it is observed that PF of the system in maintain at 0.99 , efficiency of the system is vary from 85,94 to $91,82 \%$ with voltage vary from 80 volts to 220 volts, total harmonic distortion of the system is vary from $6,60 \%$ to $12,52 \%$ with voltage vary from 80 volts to 220 volts. Input and output result waveforms are shown in the Figure 8 and Figure 9 for loading of $1.0 \mathrm{k} \Omega$ with 220 volts input voltage supply settings. 
Table 2. Results of the system at $1.0 \mathrm{k} \Omega$ with different input voltage

\begin{tabular}{ccccccccc}
\hline $\mathrm{V}_{\text {in }}(\mathrm{V})$ & $\mathrm{I}_{\text {in }}(\mathrm{A})$ & $\mathrm{P}_{\text {in }}(\mathrm{W})$ & $\mathrm{V}_{\mathrm{o}}(\mathrm{V})$ & $\mathrm{I}_{\mathrm{o}}(\mathrm{A})$ & $\mathrm{P}_{\mathrm{o}}(\mathrm{W})$ & $\mathrm{PF}$ & Efficiency $(\%)$ & $\mathrm{THD}(\%)$ \\
\hline 80.000 & 2.076 & 165.582 & 389.940 & 0.388 & 152.050 & 0.997 & 91.828 & 6.600 \\
95.000 & 1.786 & 169.331 & 389.950 & 0.389 & 152.060 & 0.998 & 89.801 & 7.530 \\
110.000 & 1.569 & 172.417 & 389.990 & 0.389 & 152.090 & 0.999 & 88.210 & 8.070 \\
125.000 & 1.399 & 174.700 & 389.960 & 0.387 & 152.070 & 0.999 & 87.046 & 7.920 \\
140.000 & 1.264 & 176.783 & 390.020 & 0.390 & 152.120 & 0.999 & 86.049 & 8.030 \\
155.000 & 1.149 & 177.739 & 389.970 & 0.389 & 152.080 & 0.998 & 85.564 & 8.040 \\
170.000 & 1.051 & 178.134 & 389.970 & 0.389 & 152.070 & 0.997 & 85.368 & 8.050 \\
185.000 & 0.967 & 178.179 & 389.970 & 0.389 & 152.080 & 0.996 & 85.352 & 8.880 \\
200.000 & 0.896 & 178.125 & 390.030 & 0.390 & 152.120 & 0.994 & 85.401 & 9.520 \\
220.000 & 0.793 & 176.641 & 389.980 & 0.389 & 152.080 & 0.990 & 85.943 & 12.520 \\
\hline
\end{tabular}

The results of PF, efficiency and THD for different voltage with different loading condition is shown in the Fig. 10, Fig. 11 and Fig. 12 respectively. Figure 10 shows the family of PF curves. The shapes of these curves are like an arc curve. Figure 11 shows the family of efficiency curves. It is seen that efficiency values decrease as the load resistance and the voltage increases. Figure 12 shows the family of THD curves. It is seen that as the load resistance and the voltage increases, the THD values also increase. From these results, PF system always more than 0.985 , efficiency is more than $85 \%$ and total harmonic distortion of current is around $4 \%$ to $12,5 \%$. The performance results of the FL based PFC is in acceptable ranges in terms of THD according to IEC 61000-3-2. The proposed FL based PFC controller is work better for the single phase AC-DC systems.

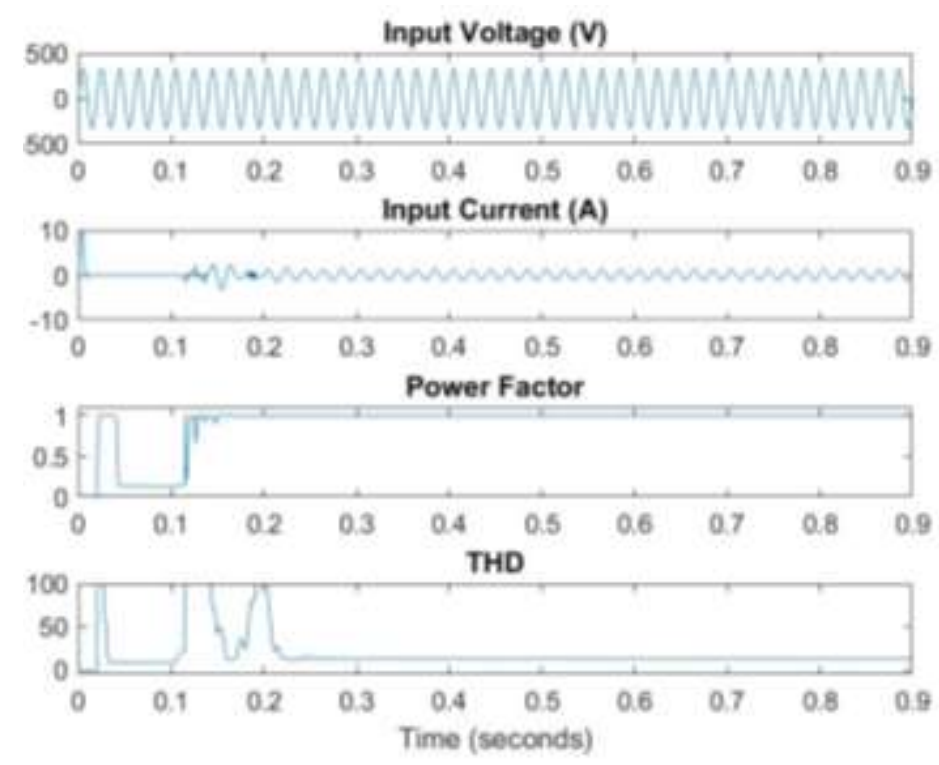

Figure 8. Input results of the system at $1.0 \mathrm{k} \Omega$ loading with input voltage of 220 volts

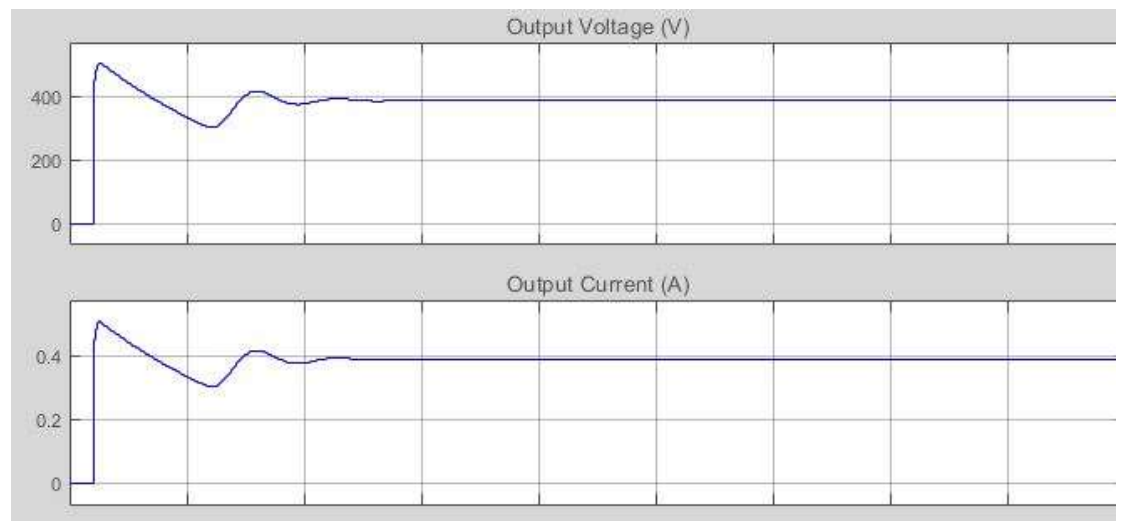

Figure 9. Output results of the system at $1.0 \mathrm{k} \Omega$ loading with input voltage of 220 volts 


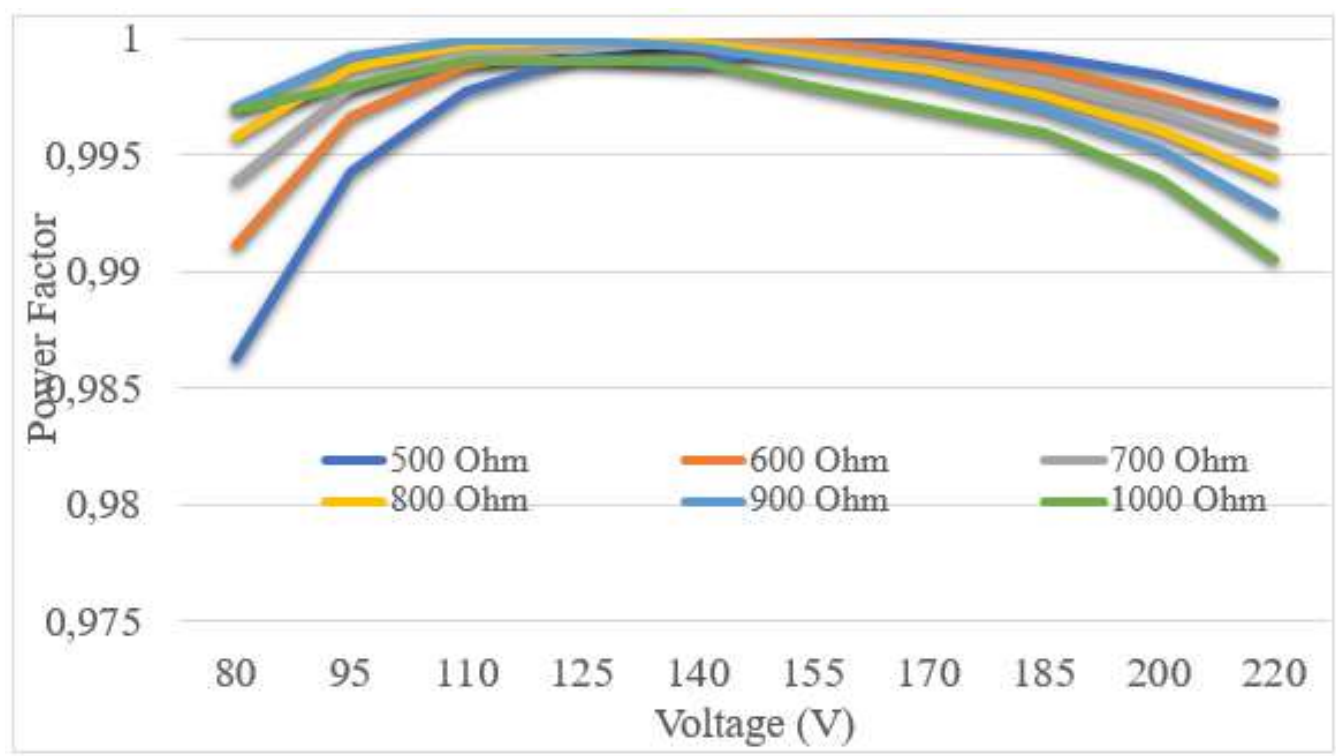

Figure 10. Power factor vs input voltage for different loads

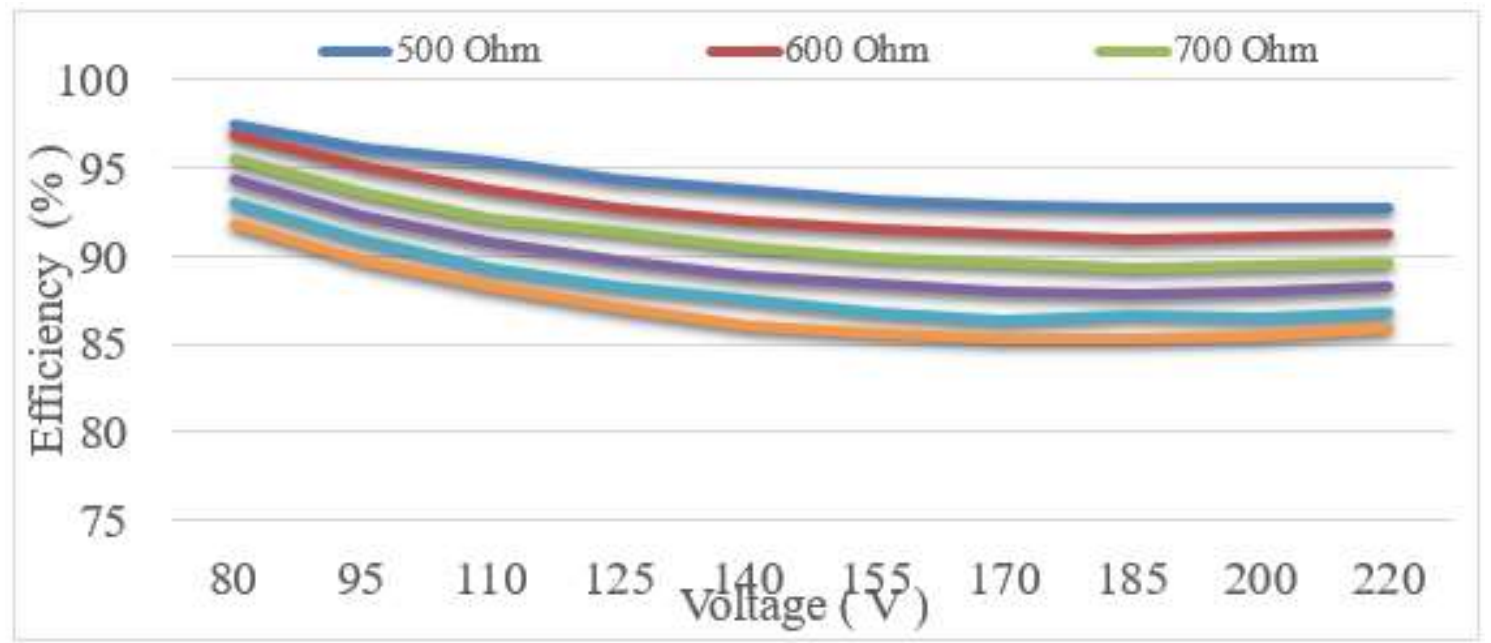

Figure 11. Efficiency vs input voltage for different loads

For the THD values given in Figure 12, taking into account the shapes of the curves, a cubicshaped polynomial regression analysis was performed in the form of $y=a x^{3}+b^{2}+c x+d$. As a result of the analysis, the following THD polynomials are obtained, with $\mathrm{V}$ being the input voltage. The THD curves family is given in Figure 13 according to cubic polynomials regression results. The cubic-shaped polynomial regression analysis is developed MATLAB - Basic Toolbox (version R2020b) with a personal computer.

$$
\begin{array}{lc}
\text { THD }=2,78 \cdot 10^{-6} \cdot \mathrm{V}^{3}-0,001157 \cdot \mathrm{V}^{2}+0,1789 \cdot \mathrm{V}-4,093 & \text { for } 500 \Omega \text { load } \\
\text { THD }=2,674 \cdot 10^{-6} \cdot \mathrm{V}^{3}-0,001126 \cdot \mathrm{V}^{2}+0,1754 \cdot \mathrm{V}-3,279 & \text { for } 600 \Omega \text { load } \\
\mathrm{THD}=5,377 \cdot 10^{-6} \cdot \mathrm{V}^{3}-0,002274 \cdot \mathrm{V}^{2}+0,3272 \cdot \mathrm{V}-9,073 & \text { for } 700 \Omega \text { load } \\
\mathrm{THD}=4,302 \cdot 10^{-6} \cdot \mathrm{V}^{3}-0,001821 \cdot \mathrm{V}^{2}+0,2666 \cdot \mathrm{V}-5,982 & \text { for } 800 \Omega \text { load } \\
\mathrm{THD}=5,37 \cdot 10^{-6} \cdot \mathrm{V}^{3}-0,002258 \cdot \mathrm{V}^{2}+0,3203 \cdot \mathrm{V}-7,602 & \text { for } 900 \Omega \text { load } \\
\mathrm{THD}=8,978 \cdot 10^{-6} \cdot \mathrm{V}^{3}-0,003722 \cdot \mathrm{V}^{2}+0,5085 \cdot \mathrm{V}-14,86 & \text { for } 1000 \Omega \text { load }
\end{array}
$$




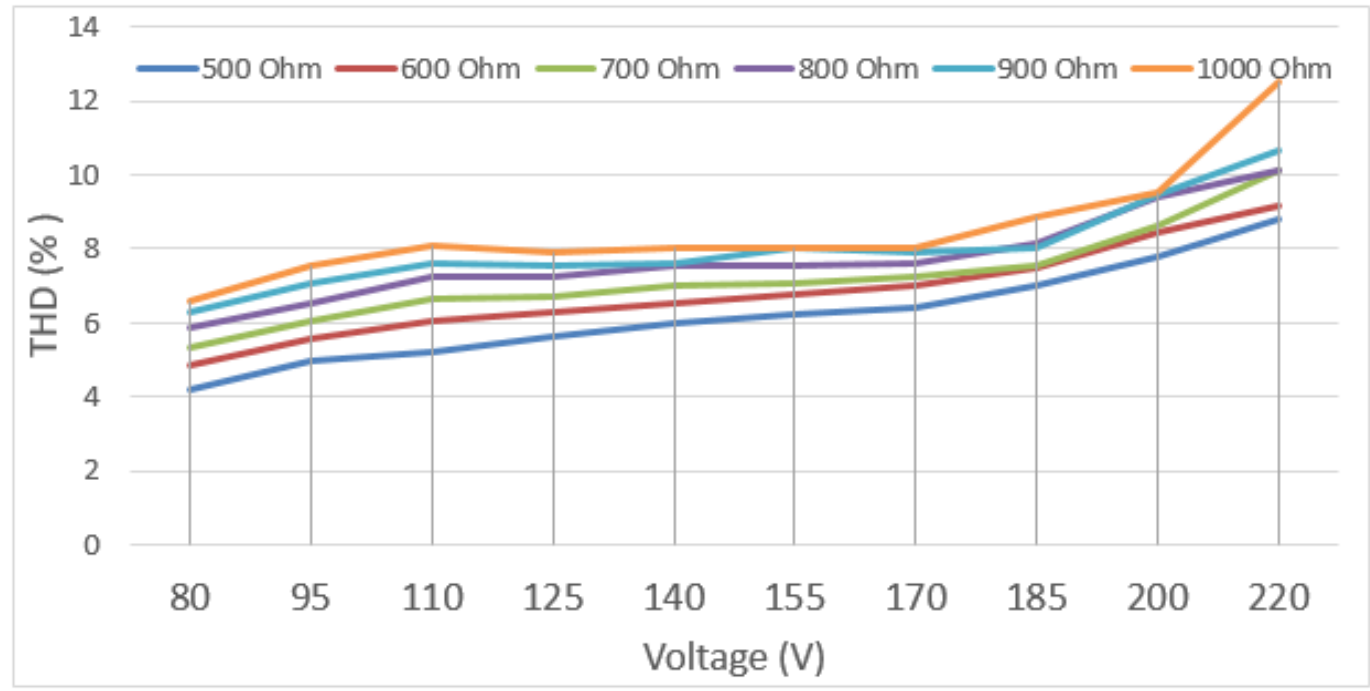

Figure 12. THD of input current vs input voltage for different loads

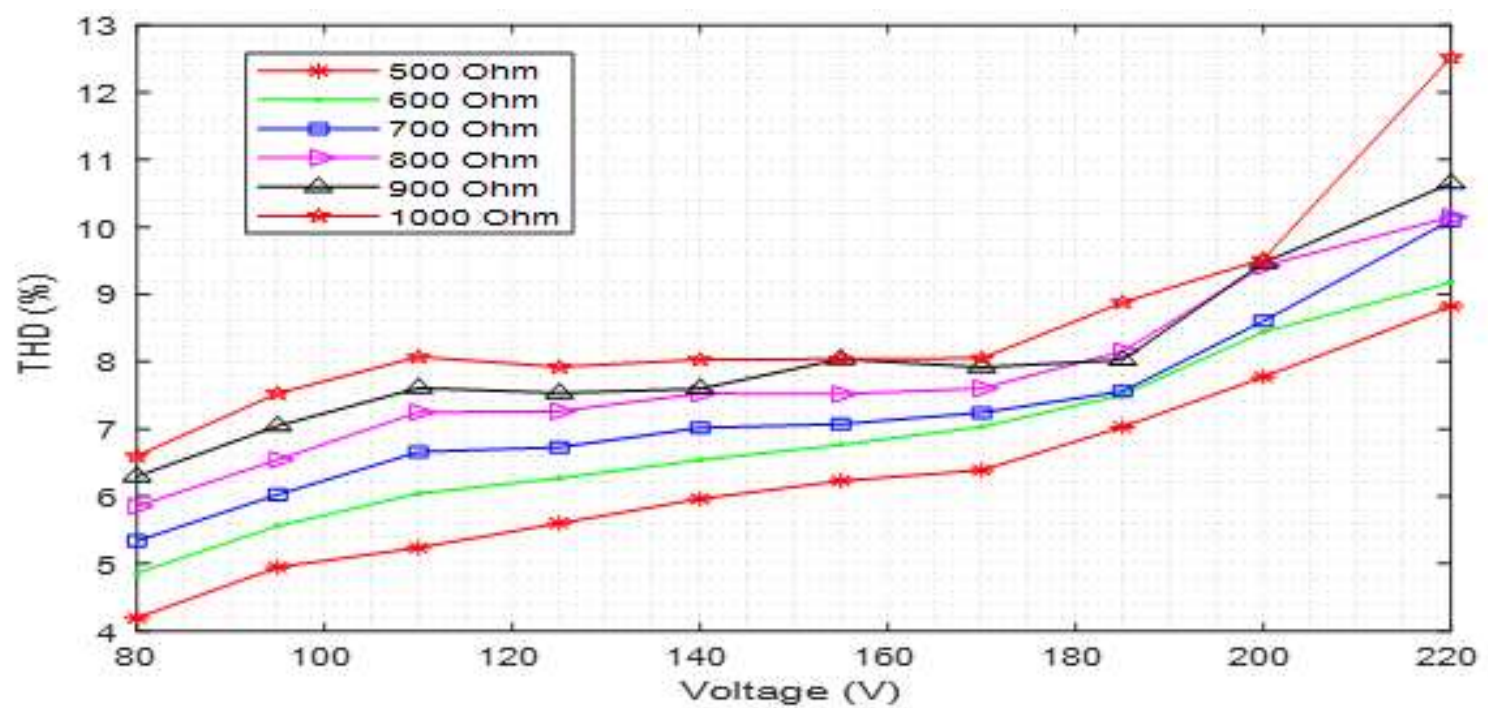

Figure 13. THD vs input voltage (V) for different loads in according with regression analysis

\section{Conclusion}

FL based PFC for single phase AC - DC system is developed and simulated. The system consists of less number of elements and have high efficiency makes this system a suitable one for PFC circuit for low power applications. The overall system is developed using MATLAB - Simulink environment in closed loop manner with FL control. The output voltage of the system is regulated using Fuzzy tuned proportional derivative controller. The stable output voltage is obtained due to Fuzzy tuned PI controller. The designed controller is outperforming the all aspects such as enhance PF, high efficiency and low total harmonic current in the system. In the near future, the production of FL controlled PFC circuits as an integrated part of the devices in nonlinear loads will result in the improvement of the low voltage network in terms of PFC and THD.

\section{Author's Contributions}

All contributions belong to the author in this paper.

\section{Statement of Conflicts of Interest}

No potential conflict of interest was reported by the authors. 


\section{Statement of Research and Publication Ethics}

The authors declare that this study complies with Research and Publication Ethics.

\section{References}

[1] Chiu H.J., Lo Y.K., Lee H.C., Cheng S.J., Yan Y.C., Lin C.Y., Wang T.H, Mou S.C. 2010. A single-stage soft-switching fly back converter for power-factor-correction applications. IEEE Trans. Ind. Electron., 57 (6): 2187-2190.

[2] Sahid M.R., Yatim A.H.M., Taufik T. 2010. A new AC-DC converter using bridgeless SEPIC. in Proc. IEEE Annu. Conf. Ind. Electron. Soc., 286-290.

[3] Jang Y., Jovanovi'c M.M. 2011. Bridgeless high-power-factor buck converter. IEEE Trans. Power Electron, 26 (2): 602-611.

[4] Su B., Zhang J., Lu Z. 2011. Totem-pole boost bridgeless PFC rectifier with simple zero-current detection and full-range ZVS operating at the boundary of DCM/CCM. IEEE Trans. Power Electron, 26 (2): 427-435.

[5] Balestero J.P., Tofoli F.L., Fernandes R.C., Torrico- Bascope G.V., de Seixas F.J. 2012. Power factor correction boost converter based on the three-state switching cell. IEEE Trans. Ind. Electron, 59 (3): 1565-1577.

[6] Fardoun A.A., Al-Saffar M. 2014. A Bridgeless Resonant Pseudo Boost PFC Rectifier. IEEE Transactions on Power Electronics, 29 (11).

[7] Singh S., Bist V., Singh B., Bhuvaneswari G. 2015. Power factor correction in switched mode power supply for computers using canonical switching cell converter. IET Power Electronics, 8 (2): 234-244.

[8] Genc N., Iskender I., Celik M. 2014. Application of interleaved bridgeless boost PFC converter without current sensing. 2014 IEEE 8th International Power Engineering and Optimization Conference (PEOCO2014), 24-25 March, Langkawi, 1-6.

[9] Kessal A., Rahmani L., Mostefai M. 2012. Power factor correction based on fuzzy logic controller with fixed switching frequency. Elektronika ir elektrotechnika, 118 (2): 67-72.

[10] Faucher J.D., Caux S., Maussion P. 2009. Fuzzy controller tuning of a boost rectifier unity power factor correction by experimental designs. Electr Eng., 91 (3): 167-176.

[11] Yu Q., Du S. 1996. Comparison of fuzzy logic and digital PI control of single phase power factor pre-regulator for an on-line UPS. Proceedings of the 1996 IEEE IECON 22nd international conference, 06 August, Taipei, 1796-1801.

[12] Suciu C., Dafinca L., Kansara M., Margineanu I. 2000. Switched capacitor fuzzy control for power factor correction in inductive circuits. 2000 IEEE 31st Annual Power Electronics Specialists Conference. Conference Proceedings (Cat. No.00CH37018), Galway, 2000, 773-777.

[13] Bouafassa A., Rahmani L., Kessal A., Babes B. 2014. Unity power factor Converter based on a Fuzzy controller and Predictive Input Current. ISA transactions, Elsevier, 1817-1821.

[14] Lenine D., Babu C.S., Shankaraiah G. 2012. Performance Evaluation of Fuzzy and PI Controller for Boost Converter with Active PFC. International Journal of Power Electronics and Drive System (IJPEDS), 2 (4): 445-453.

[15] Khoshooei A., Moghani J.S. 2004. Implementation of a single input fuzzy controller for a high power factor boost converter. 2004 IEEE Region 10 Conference TENCON 2004., Chiang Mai, 69-72.

[16] Premkumar K., Manikandan B.V. 2014. Adaptive Neuro-Fuzzy Inference System based speed controller for brushless DC motor. Neurocomputing, 138 (1): 260-270. 